\title{
Língua portuguesa para refugiados e migrantes: quem ensina aprende e quem aprende ensina ${ }^{1}$
}

\author{
Lovani Volmer ${ }^{2}$ \\ Pietra da Ros ${ }^{3}$ \\ Rosemari Lorenz Martins ${ }^{4}$ \\ Curso de Letras, Universidade Feevale, Novo Hamburgo, RS, Brasil
}

Resumo: A linguagem é um dos principais instrumentos de mediação nos processos de apropriação da cultura e a palavra, polissêmica e dialógica, de acordo com Bakhtin (1999; 2003), traz marcas socioculturais e históricas que se fazem presentes no desenvolvimento psíquico, motor e emocional dos sujeitos. A língua é, pois, fator determinante para a inserção social e sinônimo de identidade. Nesse sentido, este estudo pretende discutir, a partir de vivências de acadêmicos de licenciatura em Letras em um projeto de extensão universitária, mais especificamente, nas oficinas de Língua Portuguesa para migrantes e refugiados, a importância da língua como acolhimento e na construção da identidade, além das contribuições à formação docente.

Palavras-chave: Português como língua adicional; Identidade; Extensão universitária; Formação de professores.

Title: Portuguese language for refugees and migrants: those who teach learn and those who learn teach

Abstract: The language is one of the main mediation tools in the processes of appropriation of the culture and word, polysemic and dialogical according to Bakhtin (1999;2003), brings sociocultural and historical marks that are present in the psychic, motor and emotional development of the subjects. The language is, therefore, a determining factor to the social inclusion and synonym of identity. In this regard, this study aims to discuss, from experiences of academics of a bachelor's degree in Letters, in an university extension project, specifically in the Portuguese language workshops to migrants and refugees, the importance of the language as a shelter and in the (re)construction of identity, in addition to the contributions to teacher training.

Keywords: Portuguese as an additional language; Identity; University extension; Teacher training.

\footnotetext{
${ }^{1}$ Este estudo foi aprovado pelo comitê de ética. CAAE: 63162016.9.0000.5348.

2 Doutora em Letras, Universidade Feevale. ORCID: https://orcid.org/0000-0002-3458-1005. E-mail: lovaniv@feevale.br

3 Acadêmica de Letras, Universidade Feevale. ORCID: https://orcid.org/0000-0002-2603-9750. E-mail: pietradaros@icloud.com

4 Doutora em Letras, Universidade Feevale. ORCID: https://orcid.org/0000-0003-0658-5508. E-mail: rosel@feevale.br
} 


\section{Considerações iniciais}

Na região metropolitana de Porto Alegre, vive, atualmente, um número expressivo de refugiados senegaleses, além de haitianos, angolanos, colombianos e venezuelanos, dentre outras nacionalidades, que trabalham ou estão à procura de emprego. Essa nova realidade, em um processo de migrações, fuga de áreas em conflito e miséria criou uma nova demanda: a constituição de grupos de apoio a esses migrantes e refugiados que chegam ao Brasil e, assim, também às nossas escolas.

Nesse sentido, foi criado, em 2016, na Universidade Feevale, em Novo Hamburgo/RS, o projeto de extensão "O Mundo em NH: refugiados e migrantes - uma questão de direitos humanos". O Projeto atende semanalmente a migrantes e refugiados de diversas nacionalidades e culturas, que vieram ao país em busca de melhores condições de vida e trazem consigo as mais diversas demandas, entre elas, pouco ou nenhum conhecimento de língua portuguesa.

Assim, considerando a língua fator determinante para a efetiva inserção social e, a partir de Bakhtin (1999; 2003), sinônimo de identidade, este estudo pretende discutir, a partir de vivências de acadêmicos de licenciatura em Letras no Projeto de Extensão "O Mundo em $\mathrm{NH}$ : refugiados e migrantes - uma questão de Direitos Humanos", mais especificamente, nas oficina de Língua Portuguesa, um ambiente multicultural e multilíngue, a importância da língua como acolhimento e para a construção da identidade e também as contribuições do ensino de língua em uma perspectiva dialógica para a formação docente.

A discussão embasa-se na concepção de língua enquanto prática social, a qual se materializa em enunciados concretos, constituídos por vozes sociais que instauram a relação de alteridade (BAKHTIN, 1999). Nesse sentido, o outro (alter) tem papel primordial na construção da identidade do próprio sujeito (ego), uma vez que este só se constitui a partir daquele, ou seja, do discurso do outro.

\section{Contextualizando "O Mundo Em NH"}

Em Novo Hamburgo, no Vale do Rio dos Sinos, vive, atualmente, um número expressivo de refugiados e migrantes, que trabalham ou estão à procura de emprego. No Brasil, uma parcela significativa da população ainda carece da efetivação de seus direitos sociais, motivo pelo qual a temática da migração adquire ainda maior complexidade, exigindo a organização de ações para a inserção social desses indivíduos, no combate às diferentes formas de violência e intolerância. Nesse sentido, faz-se necessário avançar na ideia de cidadania e ver esse migrante como alguém que pode contribuir com sua cultura e experiência.

Partindo dessa premissa, iniciou, em 2016, na Universidade Feevale, instituição comunitária localizada na região metropolitana de Porto Alegre/RS, o projeto de extensão "O Mundo em NH: refugiados e migrantes - uma questão de Direitos Humanos", cujo objetivo é 
promover uma cultura de paz e tolerância, através do acolhimento e da inserção social de grupos de refugiados e migrantes e da articulação de ações educativas voltadas aos Direitos Humanos, contribuindo para a construção de uma sociedade que exerça cotidianamente sua cidadania. A maior parte das ações acontece por meio de atendimentos específicos, em especial relativos à documentação, e oficinas de ações educativas, que têm por finalidade integrá-los à comunidade e diminuir o racismo e a xenofobia. Atualmente, os cursos de Letras, Direito, Enfermagem, Fotografia, História e Psicologia da Universidade Feevale estão envolvidos no Projeto, que, ao longo desses anos, já atendeu em torno de 80 migrantes e refugiados.

Na prática, o migrante ou refugiado que têm interesse em se beneficiar do Projeto deve ir, em uma quarta-feira à noite, à Universidade, onde, a partir das 19h30min, ocorrem oficinas. Na primeira parte da noite (das $19 \mathrm{~h} 30$ às $21 \mathrm{~h}$ ), acontecem as oficinas de Língua Portuguesa, cujo objetivo principal é a aprendizagem do português, língua oficial em nosso país. Em seguida, das $21 \mathrm{~h}$ às $22 \mathrm{~h} 15$, intercalam-se oficinas de História e Cultura do Brasil, Fotografia e Psicologia, em que são abordadas temáticas específicas e de interesse dos beneficiados. Além disso, aqueles que participam do Projeto têm, também, caso necessitem, à sua disposição assessoramento jurídico e psicossocial, bem como encaminhamentos, quando necessário, à área da saúde.

No que diz respeito especificamente às oficinas de Língua Portuguesa, salientam-se as contribuições do Projeto também à formação dos futuros professores de língua e literatura, que atuam como bolsistas de extensão. As oficinas são planejadas pelos acadêmicos em conjunto com uma professora do curso de Letras, integrante do Projeto, que também acompanha as aulas. Além disso, as oficinas são espaço de observação e aplicação de estratégias de ensino e de materiais didáticos, produzidos especialmente na disciplina de "Análise e Produção de Material Didático" do Curso de Letras, de acordo com objetivos pré-estabelecidos.

\section{As oficinas de língua portuguesa: quem ensina aprende e quem aprende ensina}

A linguagem é um dos principais instrumentos de mediação nos processos de apropriação da cultura e a palavra, polissêmica e dialógica, conforme Bakhtin (1999; 2003), traz marcas socioculturais e históricas que se fazem presentes no desenvolvimento psíquico, motor e emocional dos sujeitos. É pela linguagem e na linguagem que o sujeito se constitui (BAKHTIN, 1999); é por meio dela que ele se constitui um ser social, interagindo com o outro. Então, sem a linguagem, não há sujeito.

Compreender a linguagem como instrumento de mediação para a constituição do sujeito significa também que não há sujeito pronto, mas que ele vai se completando em suas falas e nas falas do outro, porque tudo que chega à consciência do sujeito chega através do outro. De acordo com Bakhtin (2003, p. 318), "nosso próprio pensamento [...] nasce e formase em interação e em luta com o pensamento alheio, o que não pode deixar de refletir nas 
formas de expressão verbal do nosso pensamento". Dessa forma, o sujeito é dialógico, assim como a linguagem (BAKHTIN, 2003), uma vez que ambos são estabelecidos por discursos alheios e por relações dialógicas, que podem ser de aceitação, de confronto, de recusa, de negação.

$\mathrm{Na}$ verdade, tudo o que é dito (escrito) remete a um enunciado ou requer uma atitude responsiva, isto é, nenhum enunciado existe em si mesmo, por isso é sempre dialógico. Inclusive um monólogo é dialógico, porque também está permeado por outros enunciados. Contudo, apesar de ser marcado por outros enunciados, todo enunciado, assim como o sujeito, é único, singular e individual, uma vez que o enunciado produzido por um determinado sujeito, com certa intenção discursiva, em um horizonte ideológico específico em uma certa situação social e na presença de um destinatário, ficará marcado pela expressividade daquele indivíduo.

A expressividade não existe como sistema abstrato de signos, ela se dá no uso da língua em situações concretas de comunicação e, também, por meio da intenção discursiva do interlocutor. Ela é provocada no "contato entre a significação linguística e a realidade concreta (BAKHTIN, 2003, p. 311). Isto é, conforme Bakhtin (1999, p. 135), a expressividade só não está presente em elementos abstratos considerados no sistema da língua, os quais são isentos de valor apreciativo. Então, quando o sujeito se apropria das palavras do outro, apropria-se do significado e da expressividade e não das palavras da língua. A mudança de significação, por sua vez, ocorre quando o contexto apreciativo de uma palavra é deslocado para outro. Tratase, então, consoante Bakhtin (1999, p. 135), sempre de uma reavaliação.

Sendo assim, a linguagem é também fundamental para o indivíduo se inserir na sociedade e se desenvolver. Logo, para que os imigrantes e refugiados sejam aceitos e possam participar da comunidade na qual estão se inserindo, é imprescindível que aprendam a falar português, pois precisarão do português não só para se comunicar, mas, principalmente, para poderem se constituir como sujeitos nesse novo contexto. Sem o português, terão dificuldades para interagir com os outros indivíduos da comunidade, o que limita, além disso, a apropriação dos elementos culturais, que só podem ser adquiridos por meio de uma relação dialógica com o outro, nesse caso, o falante do português. Aprender a língua portuguesa, nesse sentido, é básico para os migrantes e refugiados que chegam ao Brasil, pois, através do português, poderão adquirir competências linguísticas e, também, saberes sociais para que possam ser e agir no mundo de maneira crítica.

Desde que o Projeto iniciou, em torno de 80 migrantes e refugiados já participaram das aulas de português. São crianças, homens e mulheres, entre 10 e 45 anos, de diferentes nacionalidades - Argentina, Colômbia, Filipinas, Haiti, Irã, Palestina, Senegal, Suécia, Turquia, Venezuela-, falantes de diferentes línguas, a maioria bilíngue ou multilíngue, com culturas, vivências e experiências bem particulares, com diversos níveis de escolaridade, mas, ao mesmo tempo, com um objetivo em comum: aprender e/ou aperfeiçoar sua competência linguística na língua oficial do país que os acolheu. 
Essa necessidade foi evidenciada em pesquisa realizada com os beneficiados, em que 100\% deles afirmam que conhecer a língua é importante para se inserir na sociedade e "para poder viver a vida de forma plena no Brasil" (registro de um dos entrevistados). A fala de uma migrante palestina, beneficiada pelo Projeto, também vai ao encontro dessa premissa:

nos dois primeiros anos em que estive no Brasil, senti que não vivia. Eu não me comunicava, não tinha comunicação. Não podia levar meus filhos no hospital, porque não conseguia falar. Era difícil ir ao mercado, fazer coisas simples. É como se eu não tivesse existido naqueles dois anos. (migrante palestina, 38 anos, há 17 anos no Brasil).

Quando a migrante palestina diz que parece não ter existido nos dois anos em que não sabia falar português, ela confirma a teoria de Bakhtin de que o sujeito se constitui pela e na linguagem; confirma, também que, para que essa constituição aconteça, é preciso haver interação com outros sujeitos. Embora ela acredite que não tenha vivido porque não conseguia se comunicar, a questão é bem mais complexa do que isso. Por não poder interagir, ela não pode se desenvolver, nem aprender coisas novas tampouco inserir-se na comunidade à qual pertencia fisicamente, o que está para além da simples comunicação e do estar no mundo, uma vez que, para existir, é preciso agir.

Outra migrante, proveniente da Colômbia, ressaltou:

parece que, quando chegamos, todos estão numa bolha, num filme, e a gente assiste de longe. É difícil entrar nessa bolha para se comunicar, se sentir parte, mas como a gente vai aprendendo Português, a gente consegue, e quando sabe dizer o que tem vontade é mais fácil, está dentro da bolha. (migrante colombiana, 27 anos, há 1 ano no Brasil)

É, pois, por meio da língua que a ambientação no país é firmada, ampliando as chances de buscar emprego, prosseguir com os estudos ou mesmo viver o cotidiano, compreendendo e sendo compreendido. Nesse contexto, muito mais que um meio de comunicação, a palavra proferida, no sentido bakhtiniano, é também conteúdo da própria constituição humana, uma vez que, como já explicitado, é a partir da língua que o sujeito se constitui. E, sendo a palavra portadora de constante dinamicidade e o homem o agente, já que não é só influenciado pelo meio, mas também age sobre ele, transformando-o, o dialogismo passa a ter grande importância. O dialogismo opera em qualquer produção cultural, tanto letrada quanto não letrada, verbal ou não verbal, elitista ou popular, não só no processo de comunicação, como transmissão da informação, mas como interação verbal ou não verbal.

Então, embora os migrantes e refugiados já tenham se constituído como sujeitos, pois já falam uma ou mais línguas, precisam, necessariamente, reconstruir ou complementar sua identidade, pois a comunidade da qual fazem parte agora possui outros valores, outras formas de significar. Cada meio social, cada época, possui seus enunciados, os quais circulam e são compartilhados pelas pessoas. Nesse sentido, para existir e fazer parte desse meio, o indivíduo precisa assimilar esses enunciados. Sendo assim, ele será sempre atravessado por enunciados do outro. 
Desse modo, não só o sujeito influencia o contexto, mas o contexto também o influencia. Esse contexto ideológico e o modo como ele influencia a consciência individual e vice-versa preocupou Bakhtin, na medida em que

\begin{abstract}
as palavras são tecidas a partir de uma multidão de fios ideológicos e servem de trama a todas as relações de caráter sociais em todos os domínios. É, portanto, claro que a palavra será sempre o indicador mais sensível de todas as transformações sociais, mesmo daquelas que apenas despontam, que ainda não tomaram forma, que ainda não abriram caminho para sistemas ideológicos estruturados e bem formados. A palavra constitui o meio no qual se produzem lentas acumulações quantitativas de mudanças que ainda não tiveram tempo de adquirir uma qualidade ideológica nova e acabada. A palavra é capaz de registrar as frases transitórias, mais íntimas, mais efêmeras das mudanças sociais (BAKHTIN, 1990, p. 41).
\end{abstract}

Assim, o enfoque nas aulas de português para migrantes e refugiados parte da necessidade da comunicação como facilitadora para a realização das demais atividades e como premissa para sua constituição identitária.

Cabe destacar que, em muitos casos, muitos dos participantes, antes de chegarem ao Brasil, já viveram em outros países e, por isso, aprenderam outras línguas - muitos haitianos, por exemplo, em sua rota de fuga, já tiveram contato com o espanhol, então, além do francês e do crioulo haitiano, sua língua materna, têm também noção dessa língua. Além disso, aqueles oriundos de países do continente africano falam, no geral, além do inglês ou do francês, línguas crioulas, assim como os falantes do continente asiático, como os filipinos e palestinos, que, além de sua língua materna, também falam inglês.

É nesse ambiente multicultural e multilíngue que ocorrem as aulas de língua portuguesa. $E$, em função dessa realidade, o foco inicial das oficinas é o uso da língua no âmbito social e comunicativo, em que, conforme a concepção freireana, todos ensinam e todos aprendem. Em carta endereçada aos professores, Paulo Freire diz que "não existe ensinar sem aprender" (FREIRE, 1996, p. 41 - grifos do autor), porque, para ele, o ato de ensinar pressupõe alguém que ensina e alguém que aprende.

Partindo dessa premissa, não se faz, por exemplo, uso de livro didático ou apostilas para a efetivação das aulas. Os encontros são organizados conforme o perfil, os interesses e as necessidades dos alunos, avançando, gradativamente, nas especificidades da língua, que, aos poucos, vai se tornando mais harmônica aos ouvidos e facilitando a comunicação, tanto entre os participantes ou destes em seu cotidiano. E, numa relação dialógica, enquanto os estudantes do Curso de Letras que ministram as oficinas ensinam português, vão aprendendo um pouco das línguas dos participantes e, também, sobre sua cultura e seus costumes e, dessa forma, vão também, assim como os participantes, constituindo sua subjetividade.

Além disso, quem ensina também aprende, conforme Freire (1996), porque observa a forma como o aprendiz se relaciona com aquilo que está aprendendo, com sua curiosidade e com suas dúvidas. Mas, para que isso aconteça, aquele que ensina precisa ser humilde e estar aberto a repensar o que pensou e a rever suas posições. Dessa forma, o ensinante aprende a ensinar ensinando. 
Essa concepção é muito importante para qualquer professor, porque, a cada aula, ele se depara com alunos diferentes, com sujeitos diferentes, que aprendem de forma diferente e que produzem enunciados diferentes. Logo, ele também precisa agir de forma diversa, usar estratégias variadas, adequadas para aquele grupo, naquela circunstância. Isso é ainda mais importante em se tratando de estudantes, que estão iniciando sua trajetória profissional e constituindo-se como sujeitos que aprendem e ensinam.

No que diz respeito às oficinas, é importante frisar que, especialmente quando fazia muito frio, muitos alunos não mantinham a assiduidade, pois as questões climáticas, aliadas às econômicas, faziam com que optassem por ficar protegidos. Assim, o grupo não era sempre o mesmo. Fato é que, a cada semana, aparecem novos alunos, o que exige um planejamento flexível e dinamicidade dos acadêmicos que ministram as aulas. Em tempos de isolamento social em função da pandemia, por exemplo, como é o caso da situação em que todos nos encontram neste momento, as aulas não estão acontecendo presencialmente, mas de forma virtual. Semanalmente, no mesmo dia da aula reservado para a aula, os beneficiados recebem, pelo WhatsApp, materiais e dicas para que possam, mesmo em tempos adversos, continuar ampliando seus conhecimentos linguísticos.

Dessa forma, a língua, para além de um conteúdo que precisa ser aprendido, é acolhimento, é a possibilidade de olhar para o outro e considerar o momento e suas necessidades para, a partir desses elementos, planejar o que será enviado e a melhor forma de fazê-lo.

Assim como as aulas de português se adaptaram às circunstâncias impostas pela Covid 19, as oficinas também são adaptadas aos costumes religiosos de cada participante, pois há crenças adventistas, muçulmanas e mórmons, bem como o ateísmo na mesma sala. Em função disso, os planos de aula estruturam-se em um dos pilares do projeto: a empatia. Citase como exemplo uma situação em que estava planejado, para determinada aula, abordar a variedade de comidas típicas do estado do Rio Grande do Sul, e, como essa aula cairia no período de jejum dos muçulmanos, o Ramadã, o planejamento foi revisto e a atividade ocorreu em outro momento.

Esse é, pois, o contexto em que estão inseridos acadêmicos de Letras, professores em formação, cujas vivências vão ao encontro do que preconizam os documentos legais no que diz respeito à docência, a qual é compreendida

como ação educativa e como processo pedagógico intencional e metódico,
envolvendo conhecimentos específicos, interdisciplinares e pedagógicos, conceitos,
princípios e objetivos da formação que se desenvolvem na construção e apropriação
dos valores éticos, linguísticos, estéticos e políticos do conhecimento inerentes à
sólida formação científica e cultural do ensinar/aprender, à socialização e construção
de conhecimentos e sua inovação, em diálogo constante entre diferentes visões de
mundo (BRASIL, 2015, p. 3).

Para que esse perfil docente se efetive, faz-se necessário aliar a teoria à prática, além de, constantemente, refletir sobre o que se faz. "Por que eu faço o que eu faço do jeito que eu faço?" é um questionamento que acompanha a professora orientadora e os acadêmicos a 
cada semana. Essa premissa remete a Freire (1996, p. 22), ao considerar que "o pensar certo que supera o ingênuo tem que ser produzido pelo próprio aprendiz em comunhão com o professor formador". O planejamento, cabe destacar, é realizado semanalmente - para tanto, os acadêmicos e uma professora do Curso de Letras que integra o Projeto encontram-se e avaliam a oficina anterior e, com base nela e nos objetivos que delineiam, planejam a seguinte, considerando que "é pensando criticamente a prática de hoje ou de ontem que se pode melhorar a próxima prática" (FREIRE, 1996, p. 22).

Nesse contexto, muito mais que planejar aulas de língua portuguesa e ensinar o idioma, são consideradas as vivências e as necessidades dos participantes. Para tanto, o que norteia as aulas de língua portuguesa é a língua viva, usada em diferentes situações comunicativas, que se dão a partir de gêneros textuais diversos, tanto orais quanto escritos, de forma dinâmica e interativa. É a língua enquanto atividade social, que ocorre na ação comunicativa, que se torna viva, consoante Bakhtin (1999), nas relações sociais, por meio dos enunciados, porque

toda palavra comporta duas faces. Ela é determinada tanto pelo fato de que procede de alguém, como pelo fato de que se dirige para alguém. Ela constitui justamente o produto da interação do locutor e do ouvinte. Toda palavra serve de expressão a um em relação ao outro. Através da palavra defino-me em relação ao outro, isto é, em última análise, em relação à coletividade (BAKHTIN, 1999, p. 117).

A fim de elucidar ainda mais as ações e contribuições das Oficinas de Língua Portuguesa no que diz respeito à língua como acolhimento, à cidadania e ao resgate da identidade dos sujeitos que dela participam, bem como à formação docente de acadêmicos de Letras, explicitam-se, a seguir, parte dos projetos que nortearam as oficinas ao longo de 2019.

Português como língua de acolhimento: muito mais que aprender e ensinar uma língua

As oficinas acontecem de fevereiro a dezembro. Em 2019, as atividades realizadas iniciaram com "Autorretratos", que, como o próprio nome sugere, visava à realização, nas oficinas de Língua Portuguesa, de autorretratos com palavras, propiciando um olhar sobre si e, especificamente no que diz respeito à língua, a ampliação do vocabulário e a fluência verbal. Assim, inicialmente, os participantes foram desafiados a criar, a partir das letras do seu nome e fazendo o uso de adjetivos que lhe identificassem, um acróstico.

Concluída a produção escrita, organizou-se um varal poético e cada um apresentou oralmente seu texto. Durante a leitura, os adjetivos foram sendo anotados no quadro e novas palavras foram naturalmente surgindo e sendo explicadas. Por fim, traçou-se, em conjunto, o perfil da turma, estabelecendo semelhanças e diferenças entre os participantes.

A Figura 1 traz alguns dos textos, que também possibilitaram aos participantes se conhecerem um pouco mais e, com palavras positivas, elevar sua autoestima. 
Figura 1 - Acróstico

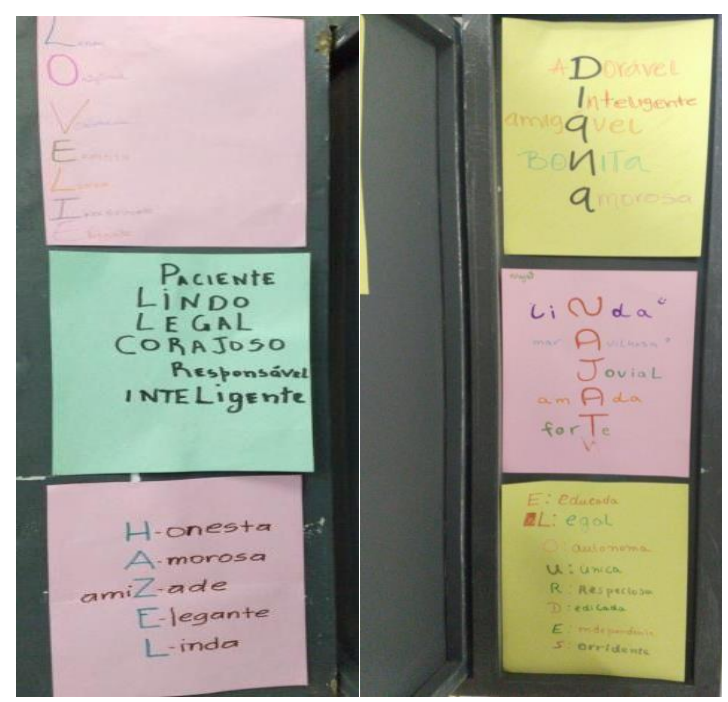

Fonte: As autoras.

Nos encontros posteriores à da produção dos acrósticos, foram lidos, analisados, estudados, trabalhados os poemas "Retrato", de Cecília Meireles, "O Autorretrato", de Mário Quintana, e "Autorretrato", de Juca Chaves. Explorou-se o vocabulário, a sonoridade, o ritmo e a melodia de cada um dos textos, que foram livremente recitados pelos alunos.

Ainda, no intuito de explorar a sonoridade das palavras, propôs-se um jogo de dominó silábico (Figura 2), o qual consiste em juntar os desenhos cujos nomes começam pela mesma sílaba (a imagem da boneca unia-se à do bolo, por exemplo). A Figura 3 explicita o momento do jogo, que foi considerado pelos alunos como divertido e de muita aprendizagem.

Figura 2 - Jogo Dominó de palavras

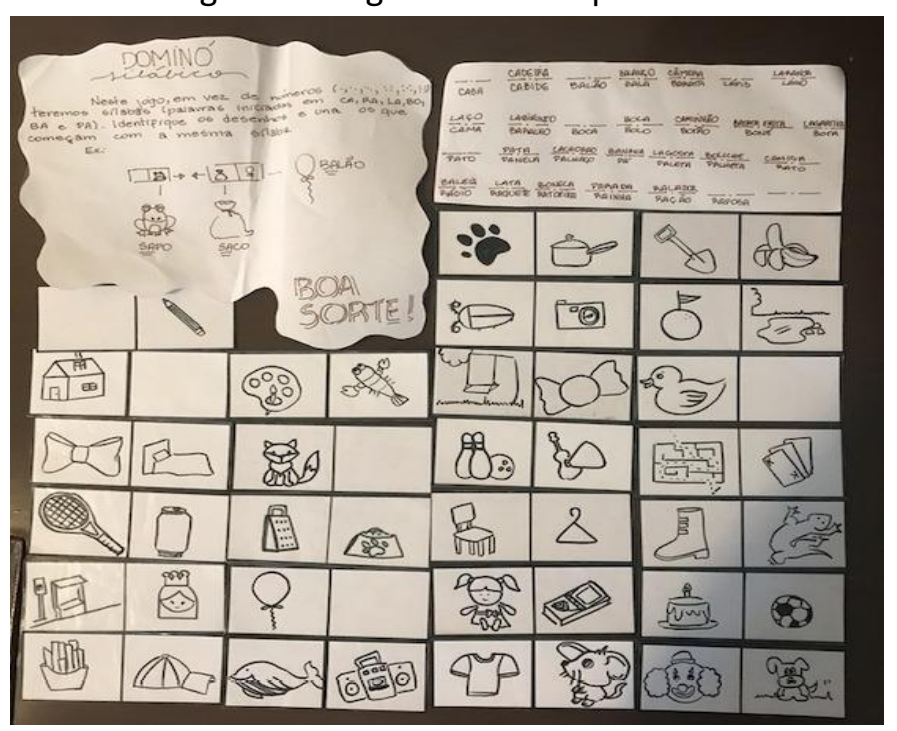

Fonte: As autoras. 


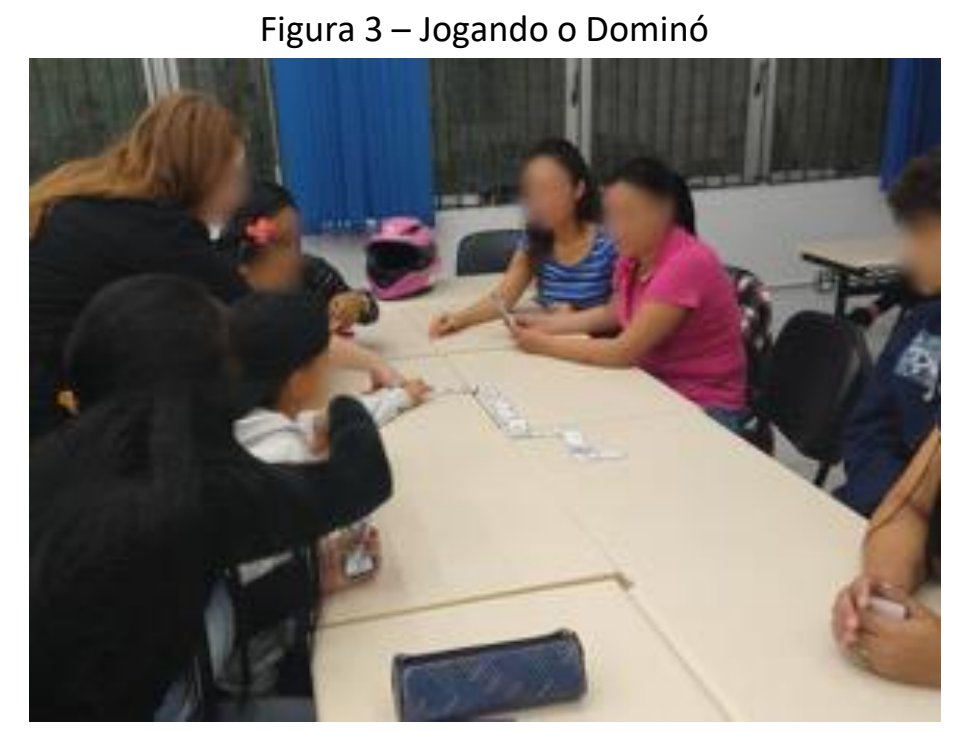

Fonte: As autoras.

Em seguida, os participantes puderam, eles mesmos, produzir seus autorretratos, escolhendo a maneira como se definiriam, tendo como referências as palavras do acróstico. Uma vez que o grupo é composto por participantes com diferentes níveis linguísticos, enquanto um está há um mês no Brasil outro está há 18 anos, alguns dos alunos escreveram em suas línguas maternas, para depois serem orientados a fazer a versão para o português. A tradução não aconteceu de forma literal, mas livre, com o intuito de se adaptar à cultura e a manter a intenção de musicalidade, quando era o caso. Nessas situações, havia palavras cuja tradução não correspondia ao sentido que se pretendia, o que gerou discussões interessantes acerca das línguas, seu léxico e seus significados. Essa flexibilidade na escolha das palavras, além de possibilitar conhecer um pouco mais a língua portuguesa, possibilitou que todos pudessem escrever e reescrever parte de si. Essas memorescências remetem a Chauí (2006), segundo a qual

há um vaivém contínuo entre as palavras e as coisas, entre elas e as significações, de tal modo que a realidade (as coisas, os fatos, as pessoas, as instituições sociais, políticas, culturais), o pensamento (as ideias ou conceitos como significações) e a linguagem (as palavras, os significantes) são inseparáveis, suscitam uns aos outros, referem-se uns aos outros e interpretam-se uns aos outros (CHAUÍ, 2006, p. 156).

Essa relação tem sua importância também no que tange à formação docente. Quando se fala do profissional de Letras, sabe-se que este deve ter consciência do que a língua abrange, levando em consideração, principalmente, o fator social e identitário. As Figura 4, 5 e 6, que seguem, trazem alguns desses textos para fins de exemplificação. 
Figura 4 - Tenho orgulho disso

TENHO ORGULHO DISSO
Eu vim tarde demais para um mundo muito
velho
Mas assumi a minha vinda
Menina preta, de tamanho médio
Estou orgulhosa de mim mesma
Independente, calma, respeitadora, sentimental
Estou orgulhosa de mim mesma
Haitiana apesar dos rumores
Estou sempre orgulhosa de mim mesma
Mesmo que eu apegue para baixo
Estou mais do que orgulhosa de mim mesma
Vi a minha vida como um conto de fadas
Porque assumi minha vinda
Graças a Deus me ter criado assim
Estou orgulhosa de mim

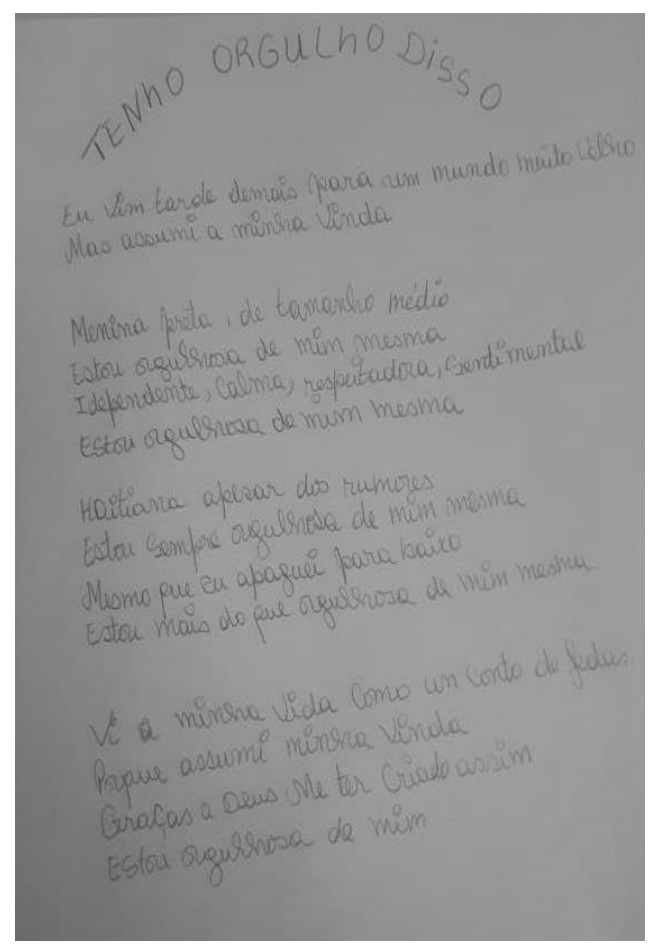

Fonte: As autoras.

Figura 5 - Ela é uma mulher forte

Ela é uma mulher forte decidida, tranquila e muito louca leva as coisas muito a sério ou como se não tivessem importância,

Ela é muito sensível, ou tem coração de pedra Ela odeia com cada fibra do seu ser, ou ama com cada pedaço da sua alma. Era tudo ou nada.

Ela não crê em intermédios

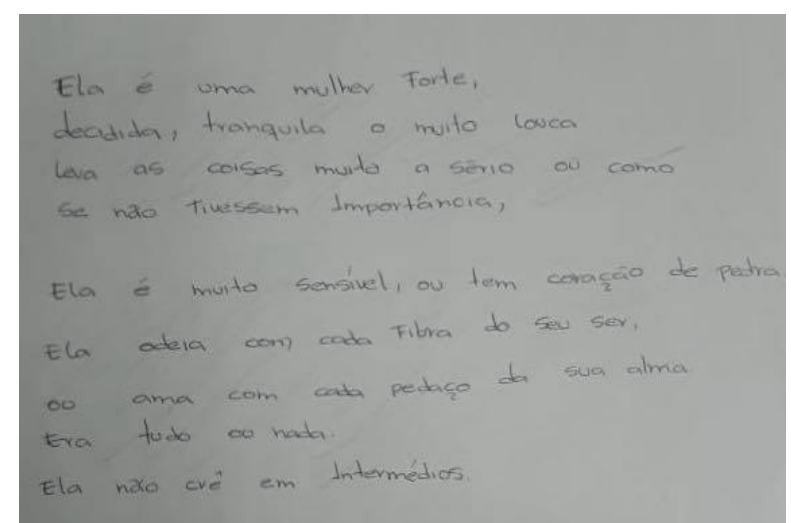

Fonte: As autoras. 
Figura 6-Meus sentimentos

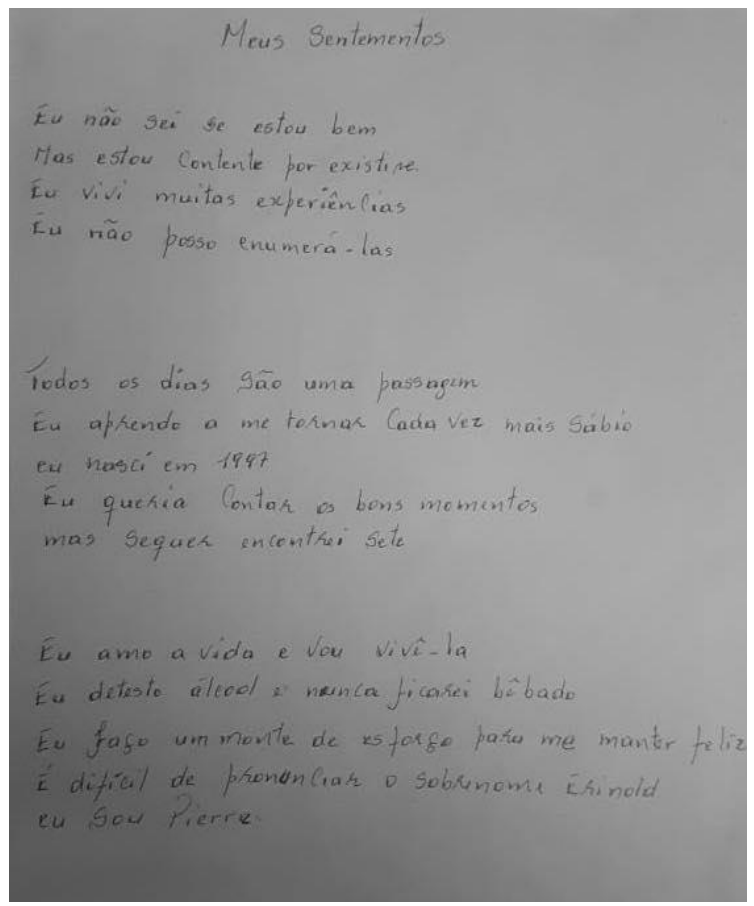

\section{MEUS SENTIMENTOS}

Eu não sei se estou bem

Mas estou contente por existir

Eu vivi muitas experiências

Eu não posso enumerá-las

Todos os dias são uma passagem

Eu aprendo a me tornar cada vez mais sábio

Eu nasci em 1997

Eu queria contar os bons momentos

Mas sequer encontrei sete

Eu amo a vida e vou vivê-la

Eu detesto álcool e nunca ficarei bêbado

Eu faço um monte de esforço para me manter feliz

É difícil de pronunciar o sobrenome Erinold

Eu sou Pierre

Fonte: As autoras.

Paralelamente à produção dos autorretratos nas oficinas de Língua Portuguesa, nas de História, discutiu-se acerca de identidade; e, nas de Fotografia, os alunos produziram autorretratos fotográficos, o que resultou, juntamente com os textos escritos, em uma exposição. A Figura 7, que segue, traz algumas dessas fotos.

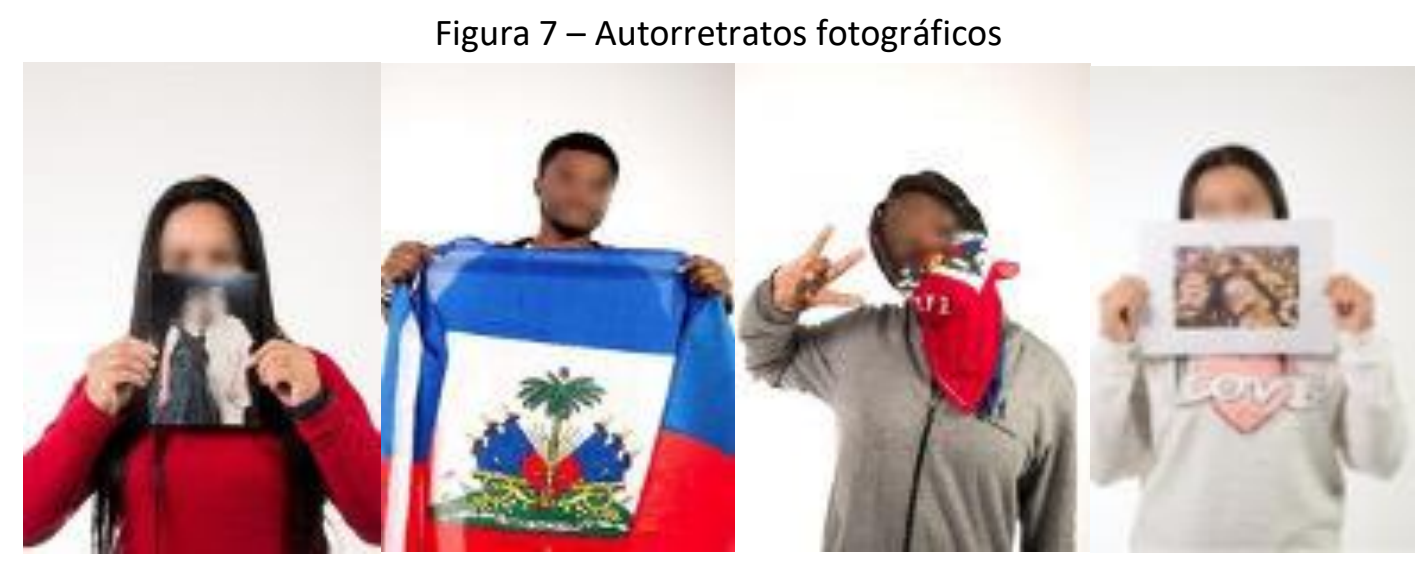

Fonte: As autoras.

Toda essa diversidade de produções foi exposta no "Sarau Culturas do Mundo 2019: Nós", evento semestral organizado por todos que se envolvem no Projeto. Para o Sarau, todos trouxeram comidas típicas e adereços de seus países, o que possibilitou uma noite de diferentes sotaques, sons, ritmos, movimentos, aromas e sabores, alinhavados por muito 
afeto, acolhimento e respeito às diferenças. A trilha sonora também foi bem variada, assim como as coreografias, que foram ensinadas e compartilhadas por todos que lá estavam.

As atividades até então giraram em torno dos autorretratos e estavam, portanto, centralizadas no "eu". Passado o Sarau e inspirados na sua temática, "NÓs", a união dos "eus", as atividades seguintes foram organizadas a partir desse mote. Inicialmente, discutiu-se acerca de formas de, em português, fazer menção ao pronome pessoal "nós", com ênfase no "a gente". Além disso, averiguaram-se as demais significações do vocábulo, que, além de pronome, é plural de "nó". Metaforicamente, "nós" é sinônimo de união, de laços que se unem.

Assim, pensando nos valores afetivos trazidos por esse termo e no poder de humanização da literatura, nos encontros seguintes, trabalhou-se a partir de minicontos. Após leituras e análises, os alunos foram desafiados a escrever seus minicontos. Foram aulas de leitura, de escrita, de discussão, encontros multiculturais, mediados pela língua, que já não Ihes soa tão estranha assim e, ao mesmo tempo, possibilita-Ihes a criação de laços. A seguir, compartilhamos alguns minicontos produzidos a partir da temática "Nós = laços". As escritas fizeram menção a uma diversidade de vínculos que podemos ter. Alguns escreveram pensando em quem os recebeu no Brasil, outros nas famílias que estão distantes em seus países de origem, ainda houve recados de mães para seus filhos ou mesmo textos que pediam por uma sociedade mais empática e equânime.

As imagens a seguir trazem alguns desses textos, junto dos nós produzidos quando da discussão acerca de "nós".

Figuras 8-Exemplos de minicontos

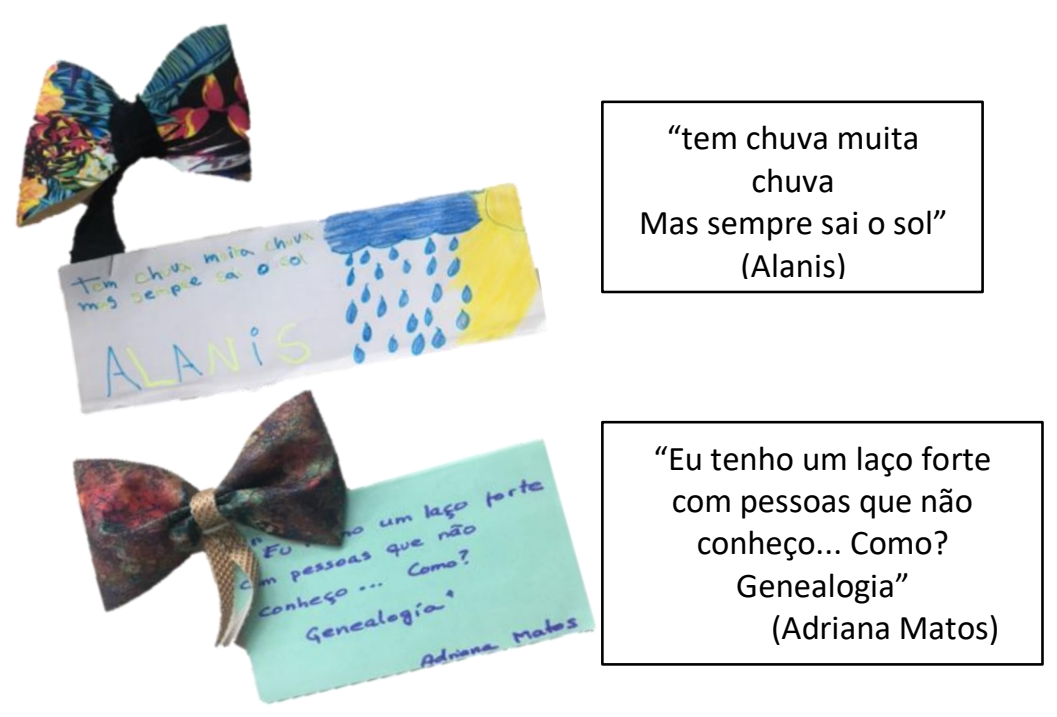

Fonte: As autoras.

Para além de ensinar e aprender português, as aulas de língua portuguesa são acolhimento, são encontros de cidadania, em que todos ensinam e todos aprendem. Para os acadêmicos do Curso de Letras, representam muito mais que uma vivência extensionista, mas 
a constituição de professores em formação. Nesse sentido, corrobora-se Santos (2015, p. 4653), o qual diz que "a aproximação do professor em formação com o ambiente real da sala de aula pode vir a construir um processo de formação de professores mais sólido, íntegro e que acompanhe as mudanças sociais que envolvem as gerações." Isso se evidencia quando os discentes envolvidos no Projeto são questionados acerca das contribuições da extensão para sua formação:

percebi, no projeto de extensão, o que eu talvez fosse demorar muito a ver se tivesse contato com a sala de aula apenas após a graduação. Entendi o que todas aquelas disciplinas sobre didática diziam com tanto vigor, na prática: a importância de reconhecer o aluno como indivíduo, com suas necessidades e capacidades, com o mundo que traz em si. (Relato de uma das bolsistas do Projeto)

Essas palavras da bolsista remetem a Tardif (2008, p. 271), para quem, "numa disciplina, aprender é conhecer. Mas, numa prática, aprender é fazer e conhecer fazendo". Muito mais que aliar a teoria à prática, trata-se da compreensão de uma premissa básica para a docência, a empatia, aliada à necessidade de conhecer os alunos, para, a partir de sua bagagem, o professor planejar suas aulas.

Cabe destacar, também, a importância da relação professor-aluno, a qual, de acordo com Tardif (2008), envolve processos cognoscitivos e socioemocionais, percebidos na ação de ensinar do professor e no que diz respeito aos vínculos afetivos. Ainda, as vivências no "Mundo em NH" oportunizam aos acadêmicos algo dificilmente compreendido a partir de experiências de terceiros: o domínio de turma - especialmente ao perceberem que a expressão "domínio" se afasta do sentido comum de dominação, tomando uma nova forma, em que professor e aluno constroem juntos o processo de ensinoaprendizagem

Nessa perspectiva, já não existe mais o conceito de "aula", em que um ensina e os demais aprendem, da mesma forma como ainda ocorre o ensino da língua portuguesa em muitas escolas, distante daquela do universo dos alunos:

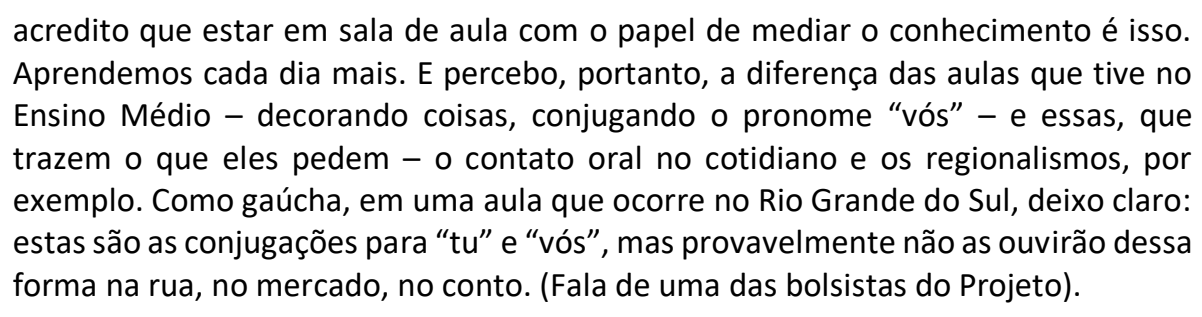

O trabalho a partir de situações reais de aprendizagem, com textos reais e, portanto, com gêneros diversos, traz, pois, para as aulas de Língua Portuguesa muitas possibilidades, a partir do conhecimento de mundo e de língua dos participantes. Essa vivência, salienta-se, também vai ao encontro do que preconiza a Base Nacional Comum Curricular - BNCC -, ou seja, um processo de ensinoaprendizagem baseado em competências. 


\section{Considerações finais}

"O mundo em $\mathrm{NH}^{\prime}$ é fundamental para que migrantes e refugiados possam se (re)constituir como sujeitos que agem no mundo e se integrar à nova sociedade. Nesse sentido, o português como língua de acolhimento é a possibilidade de eles se integrarem na sociedade, no mercado de trabalho e, enfim, conforme explicitou uma das migrantes, "sair da bolha e finalmente existir" nesse novo lugar, participar dele.

Além disso, se considerarmos a necessidade de uma formação docente mais sólida, que pretende instrumentalizar teórica e metodologicamente os acadêmicos de licenciatura em Letras e fomentar uma abordagem humanitária e crítica em aulas de português com vistas a uma prática pedagógica mais produtiva, intencional e humanizadora, que considere as particularidades dos alunos, vivências extensionistas como a discutida neste estudo contribuem sobremaneira, pois representam uma forma de ensinar aprendendo a língua em situações reais de uso. Esse processo de ensinar e aprender ao mesmo tempo possibilita aos acadêmicos, já em sua formação, vivências pedagógicas reais, para além dos estágios obrigatórios, muito mais amplas, porque cada participante do projeto vê a aprendizagem do português de forma diferente, tem curiosidades e dúvidas diferentes, decorrentes de construções subjetivas diversas, já que provêm de outras culturas, algumas delas muito diversas da nossa. Isso possibilita ao professor em formação muito mais que aliar a teoria à prática e trabalhar a língua, proporciona-lhe constituir-se também como professor mediador do processo de ensinoaprendizagem e, ainda, por meio dos enunciados do outro, constituir uma nova identidade.

Nesse contexto, e para muito além dele, o professor de Língua Portuguesa, pela língua e para além da língua, será capaz de contribuir para a transformação do meio em que vive, na busca por uma sociedade mais equânime e empática.

\section{Referências}

BAKHTIN, M. Marxismo e filosofia da linguagem: problemas fundamentais do método sociológico na ciência da linguagem. Trad. Michel Lahud e Yara Frateschi Vieira. São Paulo: HUCITEC, 1999.

BAKHTIN, M. Estética da criação verbal. 4. ed. Trad. P. Bezerra. São Paulo: Martins Fontes, 2003.

BRASIL. CONSELHO NACIONAL DE EDUCAÇÃO/MEC. Conselho Pleno. Resolução CNE/CP 2, de 10 de julho de 2015. Define as diretrizes curriculares nacionais para a formação inicial em nível superior e formação continuada. Brasília. DOU, 2 jul. 2015.

CHAUÍ, M. A linguagem. In: CHAUÍ, M. Convite à filosofia. 13 ed. São Paulo: Ática, 2006. p. 136151.

FREIRE, Paulo. Pedagogia da autonomia: saberes necessários a prática educativa. São Paulo: Paz e Terra, 1996. 
SANTOS, Camille Anjos de Oliveira; SILVA, Carla Cristie de França; OLIVEIRA, Ana Beatriz Cunha Maia de. Formação de professores: o desafio da prática. Formação de professores: contextos, sentidos e práticas, 2015. p. 1-13. Disponível em: https://educere.bruc.com.br/arquivo/pdf2017/23961_13445.pdf. Acesso em: 13 jun. 2020.

TARDIF, Maurice. Saberes docentes e formação profissional. 9. ed. Petrópolis: Vozes, 2008.

Recebido em: 02/08/2020.

Aceito em: 11/11/2020. 